\title{
GENDER (RE)CONSTRUCTION AND DESTABILIZATION OF PATRIARCHY IN JOANNA RUSS' THE FEMALE MAN
}

\author{
Mustafa KARA ${ }^{1}$
}

\begin{abstract}
Joanna Russ' The Female Man incorporates a wide range of sociological issues such as the necessity of differentiating between sex and gender, women's position within societies, gender construction, patriarchal impositions on women and men, the transitivity of gender categories, performativity in gender, and so on. These problematic cases, however, are considered in a different and effective way since they are blended with Freud's and Todorov's ideas of the uncanny and the fantastic. Through the employment of these theories, Russ endeavours to present alternative lives to her readers. Moreover, she also benefits from Butler's theory of performativity of gender in order to underscore the necessity of differentiating between gender and sex; by doing so, she explicitly highlights how slippery gender categories are and how important it is to understand that woman is a social construction, which is and has always been open to any type of change depending on the conditions of societies in terms of their structures and cultures, whereas female is a biological and physiological entity which is not possible to be changed except for a series of surgeries nowadays.
\end{abstract}

Keywords: Second wave feminism, gender construction, performativity theory, patriarchy.

Kara, Mustafa. "Gender (Re)Construction and Destabilization of Patriarchy in Joanna Russ' The Female Man". idil 6.37 (2017): 2447-2456.

Kara, M. (2017). Gender (Re)Construction and Destabilization of Patriarchy in Joanna Russ' The Female Man. idil, 6 (37), s.2447-2456.

\footnotetext{
${ }^{1}$ Okutman., Çukurova Üniversitesi, Yabancı Diller Yüksekokulu, mustafakara(at)live.com
} 


\title{
JOANNA RUSS'UN THE FEMALE MAN ADLI ROMANINDA TOPLUMSAL CINSIYETIN (YENIDEN) YAPILANDIRILMASI VE ATAERKININ ISTIKRARSIZLAŞTIRILMASI
}

\begin{abstract}
ÖZ
Joanna Russ'un The Female Man (Dişi Adam) adlı romanı cinsiyet ile toplumsal cinsiyetin birbirinden ayrılması gerekliliği, kadınların toplumlardaki durumu, cinsiyet yapılandırması, kadın ve erkeklere empoze edilen ataerkil değerler, toplumsal cinsiyet kategorilerinin geçişkenliği, performatif toplumsal cinsiyet kuramı gibi birçok sosyolojik meseleyi içinde barındırmaktadır. Bu tartışmalı meseleler oldukça farklı ve etkili bir biçimde ele alınmıştır zira Russ romanında Freud'un tekinsizlik ve Todorov'un fantastik teorilerinden faydalanmıştır. Bu teorileri romanına katan Russ, okuyucularına alternatif dünya ve yaşamların mevcut olduğunu göstermek amacını gütmüştür. Bunlara ek olarak Russ, Butler'ın performatif toplumsal cinsiyet kuramından da oldukça fazla faydalanmış ve cinsiyet ile toplumsal cinsiyet arasındaki ayrımın yapılması gerekliliği üzerinde durmuştur. Russ bunu yaparak toplumsal cinsiyet kategorilerinin ne kadar güvenilmez olduğunun yanı sıra kadın olgusunun her zaman değişime açık ve tamamen toplumların yapı ve kültürlerine göre şekillenen sosyal bir yapılandırma olduğunu, dişi sınıflandırmasının ise biyolojik ve fizyolojik bir durum olduğunu ve günümüzde ancak bir dizi cerrahi operasyonla değişebileceğini açık bir şekilde vurgulamaktadır.
\end{abstract}

Anahtar Kelimeler: İkinci dalga feminizm, cinsiyet yapılandırması, performatif toplumsal cinsiyet kuramı, ataerki. 


\section{Introduction}

As one of the most eminent activists of the second wave feminism, Joanna Russ was an author and an academic. She was beyond her time since she wrote especially in utopic forms and gave productions in fantastic literature. Her pioneering work, for sure, is The Female Man (hereafter FM), which was written in 1969 though it was not published until 1975. With her novel, Russ criticizes the established and globally recognized patriarchal norms and societies which have shaped the woman identity throughout centuries. As one of the most influential and devout supporter of the second wave feminists, Russ penned her novel in science-fiction genre so that she could present what was not presented to the world until 1970s. Because she believes that all social roles, identities, gender issues and segregations in societies are nothing but some codes, which are established by the powerful cogs of the wheel, she wants to blend utopian worlds with some realistic ones in order to manifest people that alternatives and options are always there to be realized. In her novel, Russ presents four characters, Jeannine, Joanna, Joel, and Janet, with the aim of voicing the unvoiced through touching the untouchable issues such as gender roles and performances, gender construction and deconstruction as well as enfeebling the patriarchal impositions into the societies. In other words, "Russ reinforces the idea that gender is a social construct, that patriarchy is not going to change by itself, and that individuals can succeed only when they gain access to power, even if it is done by force" (Teslenko, 2003: 124). Therefore, by giving references to the second wave feminism, French feminism as well as Freud's and Todorov's ideas over science fiction, fantasy and the uncanny, this article aims to discuss and evince the notion that gender is a performative phenomenon and that it is constructed and re-constructed according to the necessities of the powerful entities within each society as is the case with Joanna Russ' The Female Man.

\section{Joanna Russ' The Female Man As A Revolt Against Patriarchy}

According to Freud, "[t]he German word 'unheimlich' is obviously the opposite of 'heimlich' ['homely'], 'heimisch' ['native'] - the opposite of what is familiar; and we are tempted to conclude that what is 'uncanny' is frightening precisely because it is not known and familiar" (1955: 220). Therefore, it is clear that Russ benefits from Freud's idea of the uncanny and creates a fantastic world in her novel so as to reveal the repressed ideas of the male dominated society. In other words, the things, which are concealed to be kept as secrets, are revealed through the implementation of the uncanny into the storyline. Thus, the characters and their actions turn out to be the unfamiliar entities within their patriarchal societies and cultures. Estrangement is supplied through these unfamiliar entities and it renders new perspectives in order for 
the readers to change their habitual ways of thinking and to be critical of what they experience around and in their lives. Ironically, this estrangement effect creates an awareness of people's present conditions and forces them to question their very own standing among such societies and cultures. Furthermore, Todorov argues that

\begin{abstract}
[t]he fantastic occupies the duration of [the] uncertainty. Once we choose one answer or the other, we leave the fantastic for a neighboring genre, the uncanny or the marvelous. The fantastic is that hesitation experienced by a person who knows only the laws of nature, confronting an apparently supernatural event (1975: 25).
\end{abstract}

What Todorov underlines is the fact that human beings are programmed to think and behave according to the laws of nature or in parallel with the regulations of the societies' impositions into the culture and the system. Therefore, when they encounter something unnatural, or better to say, uncanny, they feel uncomfortable and name what they experience as supernatural and out of usual discourse. Fantasy, thus, is a tool in order to subvert the supressed beliefs and ideas of people within certain societies. The main function of fantasy according to Todorov, therefore, turns out to be making the invisible visible, the unquestionable questionable and the unthinkable thinkable. Fantasy and the uncanny, therefore, are implemented into the novel by Russ so as to draw attentions to the very core point of the novel, which consists of people's conventional ways of life and their lack of interest in questioning their habitual way of thinking.

Russ benefits from the second wave feminist approach in order to convey her intentions. One of the most important assumptions of the wave is the emphasis on the notion that all women are exploited bodily with the pretext that their bodies belong to their husbands, fathers, and other masculine power emblems in their families or in their societies. This primitive thought, moreover, loads other burdens on women since they are abused physically, psychologically and sexually in their communities, for their body becomes an area where men impose their very own power and potency. When women try to find their individual and free voice in an era which silences all female entities, they are victimized by domestic violence and incest. The power emblems in the society consider the female body as their own playground, where they can testify their potency whereas they also believe that sexual intercourse for women is only and only for production and motherhood. Therefore, there is a considerable irony in their attitudes and approaches to women body. The second wave feminists, opposing the argument, highlight that the female body cannot be monopolized by any single male body, thereby asserting that women possess their own bodies and it is their own choice to enjoy sexual intercourse or not. Furthermore, the second wave feminists claim that the personal is the political, for they believe that the patriarchal societies can be overcome through uniting all women globally. In order to achieve 
this, the most important thing is to know about all kinds of exploitations. This, on the whole, is only possible if women share all their personal experiences publicly. As Joanna, both the writer and the narrator of the novel, also quotes it from the instructions of her book, Brutality, "[m]an's bad temper is the woman's fault. It is also the woman's responsibility to patch things up afterwards" $(F M, 47)$. Therefore, women feel obliged to find a way to get rid of these discursive responsibilities through imposing their own experiences globally. The only possible way to make their exploitation more visible to the eye is to put forth their personal issues and make them political so that each woman who suffers from the same or similar ways of problems shouts more and more noisily within her own circle.

Considering these arguments, therefore, it is possible to claim that Russ creates her four protagonists by identifying each of them in different periods of time in different societies. Jeannine is a character, living in 1930s America while Joanna is a woman in 1960s, a period when there are upheavals due to the second wave feminist activism. Joel, on the other hand, is in a dystopic society, which is Womanland, while Janet is in a utopian community, which is Whileaway. However, the thing is that Russ juxtaposes all these characters within the same novel in a fantastic style and makes each character interact in this or that way. This is one of the points which makes the novel a product of fantasy, thereby creating the estrangement effect in the readers. By this way, she makes her readers question their inherent and present environment so as to open up new perspectives for themselves in order to come up with new replacements and inversions for the present problems.

As formerly mentioned, Joanna is both the writer and the narrator of the novel. Therefore, it is possible to assert that the four worlds she creates are helpful in showing that gender is constructed according to sociocultural norms, ideologies, discourses, institutions, and so on. In Janet's society, for instance, the very entity of language is in parallel with the one in the medieval times since people ascribe new meanings to words. Even Janet's surname, Evason, is a glimpse of what the second wave feminists endeavour to do. "Evason is not "son" but "daughter". This is your translation" (FM, 17). Her surname cannot be regarded as 'son of Eva'; on the contrary, the syllable, son, refers to the word, daughter. Therefore, this takes the readers to the idea that words connote constructed meanings. In other words, language is constructed, hence it must be abandoned and a new language should be achieved and it should be a language which will provide women a chance to reconstruct the already constructed. The agendas are considered as constructed formerly due to the fact that language is also constructed by men. Language, grammar, and also discourses, therefore, must be abandoned since they are the tools for shaping all the reality besides their feature of conveying and communicating the reality facts. These 
tools of power, thus, are also used in silencing women. Related to language, therefore, it could be inferred that masculinity and femininity are the aspects of language. Femininity defines the female as silenced and overwhelmed while masculinity attributes positive meanings to the male since masculinity is fixed and structured as well as having an authority claiming property but femininity is continuous. In other words, femininity is never fixed and it is given meanings by language continuously. Joanna, thus, figures out the problem and proposes a subversion by inventing a false language, which breaks the illusion of the dominant discourse. Furthermore, Jeannine is introduced to the readers with the third person singular pronoun, which is contrary to the other three protagonists of the novel. This is highly critical for it points out the idea that while the other characters have their subjective voices, Jeannine is portrayed by others. She cannot identify herself individually. She is considerably domestic and she cannot promote herself publicly; on the contrary, she can only exist through mental works in private.

As obvious from the language discussed above, gender is also another trouble since it is considered that it is also as fixed as language itself. Nevertheless, gender is not a fixed phenomenon; on the contrary, as is argued by Beauvoir, it is not a process of being but becoming:

\footnotetext{
One is not born, but rather becomes, a woman. No biological, psychological, or economic fate determines the figure that the human female presents in society; it is civilization as a whole that produces this creature, intermediate between male and eunuch, which is described as feminine (1956: 273).
}

She clearly addresses to the idea that sex and gender are different things, for if you are a human you must have a sex, which is only a biological entity, while gender is a process of becoming, which highlights the very idea that there are codes and discourses within each society and people are unconsciously coded with these ideals. Therefore, to put the analogy right, sex is the body while gender is the essence of the body. After all, Judith Butler, one of the founders of the performativity theory on gender issues, claims that there are various gender categories and none of these categories are settled; on the contrary, all categories are constituted by way of the enforcements people are exposed to:

Gender is in no way a stable identity or locus of agency from which various acts proceede; rather, it is an identity tenuously constituted in time - an identity instituted through a stylized repetition of acts. Further, gender is instituted through the stylization of the body and, hence, must be understood as the mundane way in which bodily gestures, 
movements, and enactments of various kinds constitute the illusion of an abiding gender (1988: 519).

Considering Beauvoir and Butler's notions about the fixity of gender identities, it would not be unjust o claim that a very good example for the so-called gender trouble is Russ herself. She is known to be a lesbian. Thus, although she is sexually a woman, she does not have a gender category which can easily be described within the inherent discourse since her lesbianism is considered as "the uncanny", which is the very self of the unfamiliarity within the society. Jeannine's boyfriend, Cal, moreover, is another good exemplification of the performativity of gender. As is found out in the novel,

\footnotetext{
[s]ometimes he likes to get dressed up. He gets into the drapes like a sarong and puts on all my [Jeannine's] necklaces around his neck, and stands there with the curtain rod for a spear. He wants to be an actor, you know. But I think there's something wrong with him. Is it what they call transvestism $(F M, 85)$ ?
}

It is crystal clear that though $\mathrm{Cal}$ is sexually a male, he has tendencies of a female, which, thus, connotes the idea that sex is fixed while gender is a very slippery area, which can be constructed and reconstructed through performances. As West and Zimmerman also put it in their work, Doing Gender, "[s]ex ... was what was ascribed by biology: anatomy, hormones, and physiology. Gender ... was an achieved status: that which is constructed through psychological, cultural, and social means" (1995: 13). Physiological and biological facts are always present to the eye so as to differentiate between male and female; however, when the question is about the differentiation between female and woman, the case turns out to be highly controversial and ironic since the former term is a topic of physiology and biology, whereas the latter is constituted by the constructions of patriarchy and its historical and cultural accumulations about womanhood:

\footnotetext{
To be female is ... a facticity which has no meaning, but to be a woman is to have become a woman, to compel the body to conform to an historical idea of 'woman,' to induce the body to become a cultural sign, to materialize oneself in obedience to an historically delimited possibility, and to do this as a sustained and repeated corporeal project (Butler, 1988: 522).
}

Considering this, it is possible to assert that Cal acts like a woman through background performances. The acting like process here is crucially important, for the attitudes of men, women, transvestites and transsexuals are all in harmony with the society's impositions. Men are taught to be men, women are taught to be women; 
thus, transvestites and transsexuals, among many other gender categories, learn to be men or women by imitating their speeches, dresses, gestures, mimics, which are the essences of gender categories, specified and coded by the societal norms, ideologies, institutions and so on. This is exactly why "what is called gender identity is a performative accomplishment compelled by social sanction and taboo" (Butler, 1988: 520).

As another example of the theory of performativity of gender, Jael, as a highly strong character in the novel, is considerably noteworthy for underscoring the transitivity of gender categories. In her time, there are both men and women; nonetheless, they have their own geographical regions. While women live in Womanland, men are in Manland. This is because Russ points out the idea that women are fed up with the patriarchal enforcements and impositions. As inferred from Jael, her society can cope with all kinds of physical and mental works, which are normally adhered and ascribed to the male identity in the patriarchal societies. Therefore, it is considerably clear that they cross their gender categories through crossing the borders of the masculine attributions. This is also related to performativity. Jael performs masculine jobs, thereby deconstructing the male identity. By doing so, she reconstructs the female identity, too. This is how Joanna Russ underlines the idea that gender is a process of becoming rather than an of being. It is, thus, clear that Jael's society is not a domestic one in the patriarchal sense. As opposing to the inherent system, Jael's society gets out of their domesticized lives and works both inside and outside of their houses. Though this is more burdening for women in accordance with the Marxist approach, it clearly portrays that women cannot be excluded from anything only because the society believes that they are incompetent or weak for performing the works which are ascribed to male identity. Hence, Jael and her society endeavour to subvert the gender roles by acquiring all the so-called manly qualities. They swap power relationships. They are assertive, violent, and capable of doing all works, attributed to men. That Jael is a murderer is also significant since it gives an idea about her violence. It is highly symbolic owing to the fact that she never feels guilty or bad; on the contrary, she feels relieved. Therefore, she represents the collective subconscious of female identity. She believes that when she kills, she comes a step closer to light, for she asserts after killing the boss that "I don't give a damn whether it was necessary or not ... I liked it" $(F M, 177)$.

Janet, moreover, is from Whileaway, which is also a future society. However, her society is a bit more different from that of Jael's, for there is no man anymore. Everybody is female and they, too, can cope with everything without the masculine intervention. When Janet introduces herself at the very beginning of the novel, for instance, she speaks as follows: 


\begin{abstract}
When I was thirteen I stalked and killed a wolf, alone ... using only a rifle. I made a travois for the head and paws, then abandoned the head, and finally got home with one paw, proof enough (I thought). I've worked in the mines, on the radio network, on a milk farm, a vegetable farm, and for six weeks as a librarian after I broke my leg. ... I've supervised the digging of the trails, delivered babies, fixed machinery, and milked more moo-cows than I wish I knew existed. ... I've fought for duels. I've killed four times. $(F M, 1-2)$.
\end{abstract}

All these masculine attributions are performed not only by Janet but also by the other Whileaway residents. This, on the whole, is in parallel with what Jael's society has performed. Both of the societies are in charge of their own lives, regardless of the existence of men around them. If one reads Janet's words above without knowing that they are a woman's words or that every woman in that society does similar things, it is possible to conclude that they are manly activities and only a man can perform such things.

\footnotetext{
Here, then, is the exciting potential for the American women of the 1970s: free access to jobs, technology, career choices, communal living, a network of friends and family, free and safe travel. But all of this can only happen once the "North Continent Wolf" is killed, once male power is broken, and women are free to establish their own society (Teslenko, 2003: 135).
}

Therefore, what Joanna Russ implies is the fact that women, too, are capable of doing such works. Thus, she portrays gender crossing and demolishes all the societal, institutional, ideological and cultural codes and impositions by way of subversions. She believes that there are free-floating signifiers which change from context to context, culture to culture and so on. Hence, she dismantles all problems before gender troubles such as division of labour, clothes, attributions and codes. By doing so, she destabilizes and the boundaries which were established before.

\title{
Conclusion
}

Joanna Russ pens her most renowned novel, The Female Man, with the intention of crossing the borders of gender categories, which are only cultural, societal, ideological, and institutional codes and impositions, established according to the necessities of each society. That her novel is a product of science fiction and fantasy is because she wants to irritate her readers so that they can open up new perspectives in order to get rid of their accustomed and fixed habitual way of thinking. It is, therefore, a wakeup-call for her readers. While writing her novel, moreover, Russ 
benefits from Freud's and Todorov's ideas of fantasy. Besides, because she is a very strong activist in the second wave feminist movement and women liberation movement, she implements all kinds of restrictive emblems in the societies in order to disturb the holders of power. She emphasizes the idea that not even a single property in societies can be monopolized by one sex; furthermore, although each sex is fixed as male and female (though through surgeries it is possible to unfix the fixed sex categories), gender crossing is possible and that it is a process of becoming rather than an act of being. It is, therefore, possible to conclude that she tries to subvert and challenge to the structured discourses. In other words, she endeavours to touch the untouchable in order to make the invisible visible.

\section{Bibliography}

Beauvoir, Simone de. "The Formative Years." Trans. Parshley, H. M. The Second Sex. Ed. Parshley, H. M. Vol. 2. Great Britain: Lowe and Brydone (Printers) Ltd., 1956. 273 - 326.

Butler, Judith. "Performative Acts and Gender Constitution; An Essay in Phenomenology and Feminist Theory." Theatre Journal, Vol. 40, No. 4 (Dec., 1988), pp. 519-531.

Freud, Sigmund. "The Uncanny." The Standard Edition of the Complete Psychological Works of Sigmund Freud. Vol. XVII (1917 - 1919). Trans. James Strachey. London: Hogarth Press, 1955.

Russ, Joanna. The Female Man. Great Britain: Orion Publishing Group, 2010.

Teslenko, Tatian. Feminist Utopian Novels of the 1970s: Joanna Russ \& Dorothy Bryant. New York and London: Routledge, 2003.

Todorov, Tzvetan. The Fantastic: A Structural Approach to a Literary Genre. Trans. Richard Howard. Ithaca and New York: Cornell University Press, 1975.

West, Candace, and Don Zimmerman. "Doing Gender." The Social Construction of Gender. Eds. Lorber, Judith and Susan A. Farrell. London: Sage Publications, 1991. 13 - 37. 